\title{
How Economic Globalization Changes International Investment Decisions
}

\author{
A. G. Pomelnikov \\ Ph. D., Faculty Member, Texas Woman's University \\ Denton, TX, USA \\ Tel: 940-898-2114Ｅ-mail: apomelnikov@twu.edu
}

Received: November 24, 2019 Accepted: December 20, 2019 Published: December 24, 2019

doi:10.5296/ijafr.v9i4.16129

URL: https://doi.org/10.5296/ijafr.v9i4. 16129

\begin{abstract}
This paper explains the need and development of new economic models to evaluate the possible outcomes of foreign investment. I consider the importance of foreign investment to emerging economies in a global economy, the effectiveness of traditional economic theory to accurately identify and quantify non-financial factors that affect investment outcomes, and the appearance of new economic models to more accurately reflect the complexity of foreign investment.

Following an extensive review of publicly available data, I find that capital flows to emerging economies is less than capital flows from developing countries, thereby producing a net loss of productive capacity. I conclude that, despite the use of new economic models, the level of global foreign investments by investor nations will continue to decline over the medium term due to a rise in anti-trade rules and regulations to retain capital and secure domestic employment within the borders of the industrialized investing nations.
\end{abstract}

Keywords: Globalization, Microeconomics, Macroeconomics, Foreign investment, Meso economics, Meta economics

\section{Background - Evolution of Economic Theory}

The forces behind international investments have evolved well past the simple goals of mercantilism, the direction of Adam Smith's invisible hand, or blind acceptance of a benign free enterprise system.

\subsection{National Economies \& Mercantilism}

International trade began early in man's history with the ancient trade routes (Cock-Starkey, 


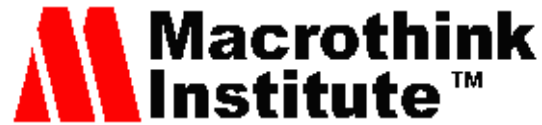

International Journal of Accounting and Financial Reporting

ISSN 2162-3082

2019, Vol. 9, No. 4

2016) has existed since ancient times, evidenced by the emergence of the Spice Trade, Incense Route, and Silk Road. The emergence of capitalism and its concept of private asset ownership, the era of colonialism, and the great voyages of discovery in the 16th century spurred the development of large national economies, competition among countries seeking privilege, and the rise of mercantilism, the latter emphasizing that economics was a zero-sum game, i.e., the gains on one side are offset by losses on the other.

Simply stated, mercantilism promoted extensive government authority to regulate the country's economy in order to expand state power over other nations. The theory equated the accumulation of precious metals as an indicator of national power and restricted the imports below the levels of exports to retain gold and silver within its borders.

\subsection{Adam Smith and the Wealth of Nations}

Scotland's Adam Smith championed the concept that trade was increscent where both sides are better off in his 1776 book The Wealth of Nations. Most importantly, his claim that the measure of a nation's wealth lay in its production and employment of its citizens, rather than the ownership of increasing warehouses of gold and silver, led to a new economic paradigm focused on economic growth - measured by the Gross Domestic Product (GDP) - and maximum employment of domestic workers. Lacking the technologies and systems necessary to operate efficiently across extended time and space, world leaders focused on national regulatory and financial policies to expand their economies with little concern about competition with other countries.

\subsection{Keynesian Economics}

The role of investment in capital growth came to the forefront due to the failure of classical economics to solve the worldwide Great Depression of the 1930s. John Maynard Keynes, a British economist, rejected the classical theories that production of goods (supply) increases demand or unemployment resulted from high wages (Horwitz, 1997), proposing that demand determines employment levels and growth cannot occur without an increase in investment (the difference between income and consumption) (Keynes, 1935). Keynesian economics and its presumption of active government intervention to achieve full employment and price stability (Jahan, Mahmud, \& Papageorgious, 2014) dominated economic thought from the end of World War II to the mid-1970s.

\subsection{Monetarism}

Milton Freedman, a Nobel Prize-winning economist at the University of Chicago, opposed Keynes' emphasis on the demand factor, reviving the classical, supply-side theory and asserting that a minimally restrained free enterprise economy would boost employment and growth (Friedman, 1962). The economist believed that inflation was the major threat to a country's economic security and proposed strict government regulation of the money supply. Its use as an economic panacea was questioned due to the failure of monetary policy to boost the economy in the early 2000s (Krugman, 2016). 


\section{A Global Economy}

At the end of the 20th century, the appearance of new infrastructures, technologies, investment approaches, and information processes enabled the national companies to become global. Supply chain advances enabled the location of production facilities anywhere in the world, encouraging new transnational corporations (TNCs) to exchange their existing higher-paid workers for lower-wage employees in another country. The development of worldwide digital records extends management control, eliminates redundancies in administration, and minimizes costly delays in identifying and resolving problems that affect the cost, quality, and cycle time of products and services.

Worldwide, billions of transactions occur electronically every second. New technologies allow immediate investment from one economy to another, creating an environment of interconnectedness around the globe. Currency interdependence integrates economies as well. Investment flows continue to become global and at the same time, more and more independent from the operation of a single country's economy (Bank for International Settlements, 62 "' Annual Report, June 15, 1992). At the same time, financial frictions do exist, complicating the investment decision beyond a pure rate of return calculation.

Contrary to general beliefs, the appearance of the modern world market, international economic relations, and world-spanning institutions are not a simple continuation of the national economic systems or a set of interrelated national economies. Today, the global economy is the intersection of micro- and macro-economic systems governed by social, political, and legal factors that determine what, how, and for whom goods and services are produced, delivered, and sold (Samuelson, and Nordhaus, 2010).

Economists generally agree that public and private investment has a substantial, positive, statistically significant effect on production output (Munnell, 1992). Nevertheless, the indirect consequences of an investment, whether validated by micro and macroeconomics, are not yet fully understood.

\section{The Dynamics of International Investment Capital Flows}

The forces behind international investments have evolved well past the simple goals of mercantilism, the direction of Adam Smith's invisible hand, or blind acceptance of Freedman's monetarism. Global capital flows exploded in the period between 2002 and 2007, increasing from $6.5 \%$ of global GDP to more than $21 \%$ in 2007, especially bank loans (350\% increase) and foreign direct investment FDI (130\%). During the 2007-2008 financial crisis, the world capital flow fell to $4.4 \%$ of global GDP and has yet to recover, equaling 6.9\% of GDP in 2017 (World Investment Report). While all categories of economies fell during the period, developing and pre-development countries were especially negatively affected.

\subsection{Investment Uncertainties}

Despite the large number of studies on investment issues (Igonina (2005); Amorozo (2000); Bakova (2003); Parter (2003); OECD (2002)), there is insufficient research to distinguish if international investments can promote lasting, indigenous structural change in a national 
economy or its effects on the much larger global economy. Assessing the effects of foreign investment is further complicated by requirements to identify and project potentially long-term or non-financial impacts that may be harmful or costly to the community, the foreign country, or the investor. International transactions are especially hazardous due to the possibility of regulatory, legal, and tax changes in the country of residence and the country of investment. Finally, the potential for expropriation, civil unrest, and exposure to uninsured natural disaster loss is usually present in developing countries, accounting for the typically higher-than-usual investment return.

\subsection{Causes of the Recent Decline in Investment Flows}

Some economists suggest that investment flows between developed and developing countries declined due to a lower level of cross-border merger and acquisition opportunities as well as a decrease in the investment rates of returns offshore. Others view the decline in global trade as reactions to tariffs and other anti-trade measures, coupled with national concerns about security and foreign ownership of land, resources, and technology. I find the decline more likely due to the rise in uncertainty about the investment outcome.

\section{The Efficacy of Investment Models}

Understanding the causes and obstacles of attracting investment capital is critical to a developing country's economic growth and reduced financial inequities among the nations of the world.

World leaders must cope with growing interactions and connections of intermeshed economic and political systems, especially the diverse impacts on developed, developing, and transitioning countries.

The difficulty of analyzing foreign investments is further complicated by requirements to identify and project potentially long-term or non-financial impacts that may be harmful or costly to the community, the recipient country, or the investor. International transactions are especially hazardous due to the possibility of regulatory, legal, and tax changes in the country of residence and the country of investment. Finally, the potential for expropriation, civil unrest, and exposure to uninsured natural disaster loss is usually present in developing countries, accounting for the typically higher-than-usual investment return.

\subsection{Dependence on Traditional Economic Models}

Classical economic theory presumes that all investment decisions are made at the micro level a simple judgement of risk versus reward - though the result has impact often extending beyond the investor and their national economy (macro level). The decision requires a combination of activity (identification of opportunity, evaluation of probable outcomes, and execution of the transaction) and analysis to determine whether predicted costs and income are realistic and valid and consider all potential factors that might affect the projected outcome. Unless income equals or exceeds costs, generating profits or capital appreciation, there is no rational motivation for investment activity under traditional economic theory. 


\subsection{Traditional Economic Models in a Global Economy}

Several Nobel Prize-winning economists have challenged the utility of traditional economic principles centered around micro and macroeconomics:

- Ronald Coase. The London-born graduate of the London School of Economics claims that microeconomics is based on simplistic price theory and leads to "courses of action [that] are inappropriate in that they lead to results which are not necessarily, or even usually, desirable" (Coase, 1988).

- Paul Krugman. Professor of Economics at Princeton University and New York Times op-ed columnist wrote that macroeconomics was an all-encompassing, intellectually elegant approach bolstered by exotic mathematics that ignored all the things that can go wrong in an economy (Krugman, 2009).

While both recognize that simple micro and macro models improve understanding of the price mechanism and the status of key aggregate economic variables, neither approach describes or analyzes the motives and actual behavior of key market participants as they engage in capital, technology, labor, production, and distribution transfers around the world.

Historically, economists and public policymakers have discounted forces that are not easily measured statistically, deeming them either insignificant or imagined. As a consequence, traditional analyses fail to consider such factors as a declining amount of non-renewable natural resources such as petroleum, pollution, labor exploitation (especially in under-developed countries), or potential international hostilities following investments in nuclear energy (Iran and North Korea). Furthermore, the influence of factors such as laws, social mores, and ill-defined national interests often exceed the boundaries of simple return/risk calculations.

A global economy with its own unique set of processes and relationships is simultaneously part of and distinct from a collection of national economies, prompting British economist Fritz Schumacher to suggest that an accurate economic analysis should include moral philosophy, psychology, anthropology, and sociology (Schumacher, 1999). Erin Beinhocker, a University of Oxford economist and McKinsey \& Company Partner, agreed, asserting that all economies are complex adaptive systems rather than the simple static systems produced by traditional economic theory (Beinhocker, 2007).

\subsection{Meso and Meta Economic Models}

Since many of the investment risks are subjective, investors often misjudge the soundness and safety of an investment in developed nations as well as those in emerging economies when deteriorated infrastructure, excessive bureaucracy, or out-of-control social welfare system is overlooked. Significant variation in a nation's cash flow can also cause problems including exchange rate misalignments and domestic credit booms and busts (Albercola, Erce, and Serena, 2012).

The shortcomings of the traditional analyses led initially to the concept of evolutionary economics (Nelson, R and Winter, S, 1982) and finally to the Micro-meso-macro system 
espoused by Australians Dopfer, Foster, and Potts (Dopfer, Foster and Potts, 2004).

The newer economic models attempt to bridge the gap between the traditional micro- and macro-economics:

- Meso economics is the study of an economic system's population of rules, a structure of rules, and a process of rules (Dopfer, 2004).

- Meta economics is a term coined by Schumacher and treats an economy as a complex, interactive, holistic living system based upon the often hidden principles of human behavior.

Whether analysis of the subjective data required in the new models is possible or more useful than older, mathematical models based on observable data remains unknown. Nevertheless, the efforts to discover new insights in the increasingly complex economic systems of the world reflect the difficulties encountered by governments, corporations, and individuals when deciding how much, when, and where to invest.

\section{Conclusions}

The world economy is transitioning to a new quality of world economic relations. Globalization has affected the international division of labor by changes in international economic relations and investments at the national and world economic levels. Investment activities have changed due to intra-country social and political influences, new relationships between countries, and a new hierarchy in the global economy.

Investors can misjudge the soundness and safety of investment in developed nations due to its deteriorated infrastructure, excessive bureaucracy, or out-of-control social welfare system, Significant variation in a country's cash flow can also cause problems including exchange rate misalignments and domestic credit booms and busts (Albercola, Erce, and Serena, 2012).

Since many of the investment risks are subjective, classical economic theory is unlikely to produce a satisfactory result, and new theories have yet to materialize. Even so, the need for international investment and their attraction continues.

While international investments are psychologically, socially, and economically complex, they, due to their stimulant effect, remain crucial for the continued economic advance of undeveloped and developing national economies. At the same time, developed countries must weigh their needs to finance growing national debt, the loss of skills and jobs due to the transfer of work to other countries, and their own needs for capital investments in social programs, national security, and domestic infrastructure.

\section{Acknowledgement}

- Methodology

My primary research method is a literature review of publicly available reports, articles, and papers to identify traditional economic and financial analysis models as well as new concepts intended to better reflect the complexity of a global network. I initially reviewed government and international sources to identify trends in global cashflows for foreign investment, 
especially in emerging economies. My conclusions are based upon my research and familiarity with economic principles, financial analysis, and political machinations.

\section{References}

Alberola, E., Erce, A., \& Serena, J. M. (2012). International reserves and gross capital flows: dynamics during financial stress. Globalization and Monetary Policy Institute Working Paper 110, Federal Reserve Bank of Dallas.

Amorozo, B. (2000). About globalization. Capitalism XXI (Trans. from English Liubavskii A.G. Nizhny Novgorod). Publishing House of the University of Nizhni Novgorod.

Bakova, E. A. (2003). Metaeconomical processes as the basis for globalization. Dis. of cand of econ. sciences: 08.00.01 - Magazine. Russia.

Bank for International Settlements. (1992, June 15). Annual Report.

Beinhocker, E. (2007, April 5). The Origin of Wealth: Evolution, complexity, and the Radical Remaking of Economics. Random House Business.

Chesnais, F. (1994). The globalization of capital. Paris: Syros Editions.

Coase, R. (1988). The Problem of Social Cost. The Firm, the Market, and the Law. Chicago: University of Chicago Press. Retrieved Shttps://www.dallasfed.org/ /media/documents/research/ei/ei0303.pdf

Cock-Starkey, C. (2016, September 20). 8 trade Routes That Shaped World History. News Central Asia. Retrieved from http://www.newscentralasia.net/2018/02/27/8-trade-routes-that-shaped-world-history/

De Long, V., \& Froomkin, M. (1997). The Next Economy. Oxford: Oxford University Press.

Dopfer, K., Foster, J., \& Potts, J. (2004). Micro-Meso-Macro. Journal of Evolutionary Economics, 263-279. 14, Retrieved from https://papers.ssrn.com/sol3/papers.cfm?abstract_id=721599

Fernand, B. (1982). Civilization and Capitalism, 15th-18th Century: The perspective of the world. University of California Press.

Friedman, M. (1962). Capitalism and Freedom. University of Chicago Press.

Horwitz, S. (1997, January 1). Understanding Say's Law of Markets. Foundation for Economic Education. Retrieved from https://fee.org/articles/understanding-says-law-of-markets/

Igonina, L. L. (2005). Investments: Proc. Manual. Ekonomist.

Immanuel, W. (2004). World-Systems Analysis: An Introduction. Durham, North Carolina: Duke University Press.

Jahan, S., Mahmud, A., \& Papageorgiou. (2014, September). What is Keynesian Economics?. International Monetary Fund: Finance \& Development, 51(3). Retrieved from https://www.imf.org/external/pubs/ft/fandd/2014/09/basics.htm 


\section{Macrothink}

International Journal of Accounting and Financial Reporting

ISSN 2162-3082

2019, Vol. 9, No. 4

Keynes, J. (1935). The General Theory of Employment, Interest and Money. Retrieved from http://cas2.umkc.edu/economics/people/facultypages/kregel/courses/econ645/winter2011/gen eraltheory.pd

Krugman, P. (2009). How Did Economists Get It So Wrong?. New York Times, September 2. Retrieved from https://www.nytimes.com/2009/09/06/magazine/06Economic-t.html

Krugman, P. (2015). Why Monetarism Failed. The Opinion Pages, New York Times, April 13. Retrieved from https://krugman.blogs.nytimes.com/2016/04/13/why-monetarism-failed/

Menger K. (1992). Foundations of Political Economy. Austrian school of political economy.

Munnell, A. (1992). Infrastructure Investment and Economic Growth. Journal of Economic Perspectives, 6(4), Fall, 194.

Nelson, R., \& Winter, S. (1985). An Evolutionary Theory of Economic Change. Harvard University Press. Retrieved from https://www.hup.harvard.edu/catalog.php?isbn=9780674272286

OECD. (2002). Measuring the Non-observed economy: A Handbook. Retrieved from http://www.oecd.org

Porter, M. E. (1990). The competitive advantage of nations. New York: Free Press.

Samuelson, P., \& Nordhaus, W. (2009). Economics (19th ed.). McGraw-Hill Education.

Schumacher, F. (1966). Buddhist Economics. Asia: A Handbook. Anthony Blond Ltd. Retrieved from https://centerforneweconomics.org/publications/buddhist-economics/

Schumacher, F. (1973). Small is Beautiful: Economics as if People Mattered (Harper Perennial Reprint edition).

Schumpeter, J. (1995). Capitalism, Socialism and Democracy. Economics.

Weber, M. (1978). Economy and Society. University of California Press.

World Investment Report 2018. (n.d.). United Nations Conference on Trade and Development.

\section{Copyright Disclaimer}

Copyright for this article is retained by the author(s), with first publication rights granted to the journal.

This is an open-access article distributed under the terms and conditions of the Creative Commons Attribution license (http://creativecommons.org/licenses/by/4.0/) 